\title{
Legal Advocacy For Catfish Cultivation Groups As An Effort To Improve The Economy In Facing The Covid 19 Pandemic In Mojorang Agung Wondayu Village, Sidoarjo, East Java, Indonesia
}

\author{
Sutrisno $^{1}$, Mas Anienda Tien $\mathrm{F}^{2}$, Rohmatul Faizah ${ }^{3}$, Hervina Puspitosari ${ }^{4 *}$ \\ 1,2,3,4 Lecturer at the Faculty of Law, Universitas Pembangunan Nasional \\ "Veteran" Jawa Timur, Indonesia. \\ ${ }^{*}$ Corresponding Author: \\ Email: hervina.ih@upnjatim.ac.id
}

\begin{abstract}
.
Empowerment of catfish advertising cultivation for the community can increase the income source of rural communities and also as an effort to expand employment opportunities for rural communities through the provision of existing land and water in the village of Mojorangagung Wondayu Sidoarjo, East Java, Indonesia. Fish farming business groups in running their business require a business license as a form of legality. Assistance and roles and cooperation with various related agencies are needed in the progress of fish farming business groups, for example, Cooperation with the Department of Agriculture and Food, Cooperation with Universities, one of which is with the National Development University "Veteran" East Java so that assistance can be carried out in managing its legality and can be carried out assistance in cultivation and marketing as well as various other collaborations with related agencies are also needed. The management of legal entities for fish farming groups is very important, apart from being an obligation some rights can be obtained by fish farming groups that have legal entities including being able to receive assistance from the government in the hope that fish farming business actors in the future can be independent and carry out sustainable fisheries business.
\end{abstract}

Keywords: Advocacy, Legality, Group, Aquaculture, Fish

\section{INTRODUCTION}

Indonesia is an archipelagic country consisting of many islands with a potential area consisting of one-third of land and two-thirds of being surrounded by waters or oceans. The fishery sector is one of the potential sectors which is a source of economic growth as well as a source of livelihood for the majority of the community. Fisheries make a major contribution to the creation and development of home industries, micro, small and medium enterprises, and large-scale export industries. Increased economic growth is shown as well as contributing to efforts to improve community welfare through processing and marketing of fishery products. Empowerment of aquaculture in the fishery sector to increase the economy, village income, and people's living standards in economic during the Covid-19 pandemic and as a manifestation of village food security. Catfish as one of the freshwater fish commodities is very popular in the community and is widely consumed by the 
community. Besides having good taste, catfish also has a high selling value and is easy to market. Empowerment of catfish advertising cultivation for the community can increase income sources for rural communities and also as an effort to expand employment opportunities for rural communities through the provision of existing land and water in the village of Mojorangagung Wondayu Sidoarjo, East Java, Indonesia.Demand for catfish consumption in East Java, especially the Regency area Sidoarjo and the East Java region are still very high so that it becomes an opportunity for the community to cultivate catfish which can provide benefits if managed intensively and can be a social function in addition to generating profits for the village community.

Business segmentation can also be an option for cultivators from hatcheries, nursery, and grow-out. To cultivate catfish enlargement, it must be cultivated intensively where catfish are cultivated to be able to grow to the maximum market size through optimizing the provision of the environment as well as management of feed and water as well as pest and disease control to achieve marketing standards for consumer consumption. Mojorangagung Village is one of the villages in the Wonoayu District area which has the potential for the development of catfish farming business, due to the availability of adequate land both in the yard and outside the yard, and the availability of water sources continuously, both river water and groundwater.The importance of legality of legal entities for cultivation groups. A deed is a form of a written agreement. According to Subekti, a deed is not a letter but must be interpreted as a legal act, derived from the word acte which in French means action.[1] A deed is a form of the existence of a legal act or a deed is a legal act itself. According to Sudikno Mertokusumo, a deed is a signed letter containing the events that form the basis of a right or an engagement, which was made from the beginning intentionally for proof. [2] So that the legality of fish farming groups is needed in Pokdakan Mina Mojo, Mojorangagung Village, Wonoayu District, Sidoarjo Regency.

\section{METHODS}

The method used in writing the results of this community service through the following stages:

1) Does observation: before conducting field observations, a permit application is made to the Head of Mojorangagung Village / Head of Village to carry out activities in the Mojorangagung Village / Village Area. After getting permission, proceed with observing. Observations were made to get a clearer picture of the existing conditions, to know the potential and constraints from various aspects. Observations were made by digging up information from the Mojorangagung Village Head, Chairperson, and members of the Fish Cultivator Group. Observations, documentation, and recordings were also carried out to obtain the necessary data. 
2) Analysis of potentials and problems: all information from observations is carried out by analyzing existing potentials and problems. The next step is to sort out the most pressing potentials and obstacles to be resolved. The initial conclusion was that the fish cultivator group in Mojorangagung Village did not yet have clear legality so that the process of cultivating and developing fish was not optimal.

3) Drafting legal legality by the Servant team from the Faculty of Law of the Universitas Pembangunan Nasional "Veteran" Jawa Timur, Indonesia to produce a product in the form of legality which will later make it easier for groups of cultivators in Mojorangagung Village in developing fish cultivating businesses.

4) Legal or legal products: at this stage, assistance is needed in establishing legality from the service team from the Faculty of Law, UPN Veterans, East Java. Then analyze what legal assistance is needed.

5) Implementation: An implementation that will be carried out in the field with the stages of counseling and legal assistance. Counseling and legality assistance is carried out to members of fish cultivators in Mojorangagung Village so that the farmer groups have knowledge and understanding related to legal legality in developing their business.

6) Evaluation: at the evaluation stage, a review will be carried out on the legality counseling and assistance that has been provided, as well as a review on the motivation of the participants (fish cultivators group) in implementing the knowledge from the legal assistance that has been provided.

\section{RESULT AND DISCUSSION}

Facing the Covid 19 pandemic which has an impact on the economic sector and people's income, efforts need to be made to encourage and revive the community's economy, one of which is the empowerment of fish farming. Fish farming where there are various kinds of species, each species of fish has various environmental criteria. There are also various methods of fish farming, including through fish ponds, aquaponics tanks, or also through cages. Ease of fish farming to support the economy of villagers with small capital is expected to be an alternative to supporting the economy of villagers who are currently experiencing the impact of the Covid 19 pandemic. The first step in efforts to empower fish cultivation can be done through the formation of aquaculture business groups.

A group is a group of people consisting of two or more people who influence each other and are interdependent who work together to achieve a common goal or goal [3]. According to Baron \& Byrne in Markum, a group is a group of people who bind themselves in a coherent bond. The strength or cohesiveness of the group is determined by the extent to which a group is perceived as a compact unit, or commonly called entitativity [4]. Meanwhile, according to Soetarno, community groups are small groups in society that become a forum for individuals who have the same interests and have agreed to norms, among others, by sharing and helping each other [5]. The need 
for a Notary Deed as demand for legal certainty in various economic relations in the development of fish farming. The need for a Notary Deed to ensure legal certainty is also needed by the fish farming group in Pokdakan Mina Mojo, Mojorangagung Village, Wonoayu District, Sidoarjo Regency as an artificial legal entity in carrying out legal actions.Mojorangagung Village is an area of Wonoayu District which is the easternmost bordering Sidoarjo District.

Mojorangagung Village has great potential for the development of freshwater fish farming because the area has large land and good water availability both in quality and quantity. In Mojorangagung village, community cultivation uses earthen ponds, tarpaulins, and concrete. In the village of Mojorangagung, there is an enlargement/cultivation group under the name Mina Mojo. The management of the Fisheries group is as follows with the name of the group "Mina Mojo" chaired by M. Romandon, Secretary by M. Jainul Aminin, Treasurer by Suryani. The total number of management members of the fish farming group is 10 (ten) people. The following is the location of catfish farming in Mojorangagung village, Wonoayu, Sidoarjo

Fig.1 Fish Cultivation Place

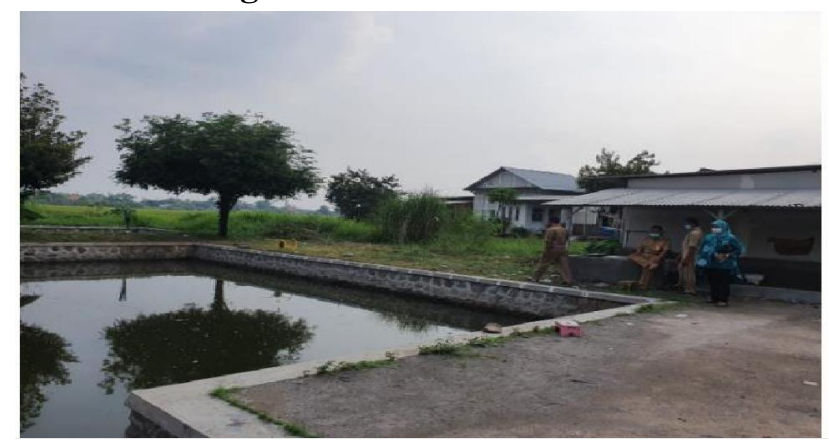

Fig 2. Mojorang Agung Village Office

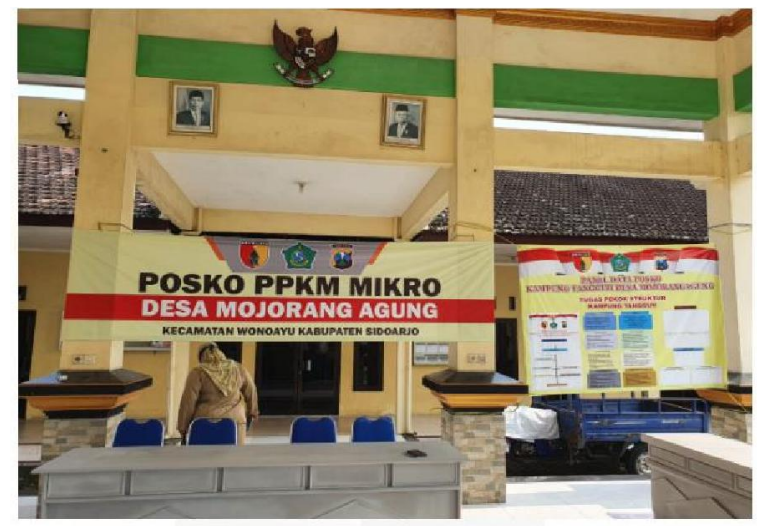

Through the empowerment of groups of fish cultivators that have been legalized, it is hoped that they will be able to provide an umbrella for business activities carried out in the development of fish farming, especially in starting a catfish farming business. The fish pond that has been prepared by the Mojorang Agung village in starting a fish farming empowerment business, especially catfish, is 
the main capital in business development. Fish ponds are artificial waters as a place for fish cultivation which can also be developed as fishing grounds that can attract visitors as an alternative to developing fish farming businesses and can also be used for fish breeding businesses that are prepared for breeding. The independence of aquaculture business actors through efforts to establish and strengthen group institutions through their legality is expected to further support the success of development in the fishery sector.

Fish farming business groups in running their business require a business license as a form of legality. The legality of a fish farming group formed with the principles of common interests, natural resources, socio-economic, cooperation, kinship, mutual trust, and harmonious relations between the management of the fish farming group and the local village community so that each member of the group can feel ownership and can enjoy the benefits as much as possible. -the magnitude of the activities of the fish farming group and provide social functions for the village community. Assistance and roles and cooperation with various related agencies are needed in the progress of fish farming business groups, for example, Cooperation with the Department of Agriculture and Food, Cooperation with Universities, one of which is with the National Development University "Veteran" East Java so that assistance can be carried out in managing its legality and can be carried out assistance in cultivation and marketing as well as various other collaborations with related agencies are also needed.In the regulation of Article 1 point 16 of Law Number 31 of 2004 concerning Fisheries which was later amended by Law Number 45 of 2009, a Fishery Permit is a written permit that must be owned by a fishery company to conduct a fishery business using the production facilities listed in the permit. the. SIUP must be owned by fish cultivators.

Fish cultivators that are carried out individually or by companies are required to have a SIUP, but there are exceptions for small fishermen and/or small fish cultivators to have a SIUP.The distribution of government assistance to fish cultivators has not been allowed to independent cultivators since 2017. Regulation of the Director-General of Aquaculture No. 53/PER-DJPB/2017 regulates the stimulation of assistance for pokdakan to support increasing aquaculture production through fish cultivator groups. The existence of pokdakan makes it easier for fishery instructors to facilitate the interests of fish cultivators in legality, technology transfer, and production management assistance.[6]The management of legal entities for fish farming groups is very important, apart from being an obligation some rights can be obtained by fish farming groups that have legal entities including being able to receive assistance from the government in the hope that fish farming business actors in the future can be independent and carry out sustainable fisheries business. 


\section{CONCLUSION}

Empowerment of aquaculture in the fishery sector to increase the economy, village income, and people's living standards in economic recovery during the Covid 19 Pandemic and as a manifestation of village food security. Catfish as one of the freshwater fish commodities is very popular in the community and is widely consumed by the community. Besides having good taste, catfish also has a high selling value and is easy to market. Empowerment of catfish advertising cultivation for the community can increase the income source of rural communities and also as an effort to expand employment opportunities for rural communities through the provision of existing land and water in the village of Mojorangagung Wondayu Sidoarjo, East Java, Indonesia. Fish farming business groups in running their business require a business license as a form of legality. The legality of a fish farming group formed with the principles of common interests, natural resources, socio-economic, cooperation, kinship, mutual trust, and harmonious relations between the management of the fish farming group and the local village community so that each member of the group can feel ownership and can enjoy the benefits as much as possible.

The magnitude of the activities of the fish farming group and provide social functions for the village community. Assistance and roles and cooperation with various related agencies are needed in the progress of fish farming business groups, for example, Cooperation with the Department of Agriculture and Food, Cooperation with Universities, one of which is with the Universitas Pembangunan Nasional "Veteran" Jawa Timur so that assistance can be carried out in managing its legality and can be carried out assistance in cultivation and marketing as well as various other collaborations with related agencies are also needed. The management of legal entities for fish farming groups is very important, apart from being an obligation some rights can be obtained by fish farming groups that have legal entities including being able to receive assistance from the government in the hope that fish farming business actors in the future can be independent and carry out sustainable fisheries business.

\section{ACKNOWLEDGMENTS}

The authors are grateful to the Chancellor of the Universitas Pembangunan Nasional "Veteran" Jawa Timur, to LPPM Universitas Pembangunan Nasional "Veteran" Jawa Timur, Faculty of Law Universitas Pembangunan Nasional "Veteran" Jawa Timur, Head of Mojorang Agung Village, Group Pokdakan Mina Mojo Fish Cultivation, Mojorang Agung Village, Wonoayu District, Sidoarjo Regency, East Java, Indonesia.

\section{REFERENCES}

[1] Subekti, 1980, Pokok-pokok Hukum Perdata, Intermasa, Jakarta, pp. 19

[2] Sudikno Mertokusumo, 1999, Mengenal Hukum Suatu Pengantar, Liberty, Yogyakarta, pp. 116 
[3] Munandar, A.S, 2020, Psikologi Industri dan Organisasi, Universitas Indonesia, Jakarta

[4] Markum, Enoch.M, 2020, Psikologi Sosial, Penerbit Universitas Terbuka, Jakarta

[5] Soetarno, 1989, Psikologi Sosial, Kanisus, Yogyakarta

[6] Ira Triswiyana, Ayu Permatasari, Juandi, Sebaran dan Produksi Kelompok Pembudidaya

Ikan Air Tawar di Kecamatan Muntok, Bangka Barat, Journal of Aquatropica Asia, Volume 5, Nomor 1, Tahun 2020, pp. 22 